\title{
FRACTURE STUDIES IN UPPER CRETACEOUS AND UPPER JURASSIC STRATA ON THE UPPER ALASKA PENINSULA AND LOWER COOK INLET
}

by

Robert J. Gillis ${ }^{1}$, Mary R. Maley ${ }^{2}$, Rachel A. Frohman², and C. Shaun Peterson ${ }^{3}$

Conventional reservoir quality throughout much of the Cook Inlet Jurassic stratigraphy is commonly believed to be challenged by the effects of authigenic clay and zeolite cementation and compaction (for example, Helmold and others, in press), although there is now evidence for locally good conventional reservoirs as well (Helmold and others, and Stanley and others, this report). To better understand fracture porosity and unconventional reservoir potential within Mesozoic basin fill lithologies, DGGS, in collaboration with the University of Alaska Fairbanks (UAF), has begun field work on a two-year study to characterize systematic fracture sets observed throughout most of the Jurassic and Cretaceous stratigraphy (fig. 2). On the Iniskin Peninsula, the location of active oil seeps is largely controlled by a prominent regional fracture set (for example, Detterman and Hartsock, 1966), and thus understanding fracture persistence and connectivity will also provide insights into hydrocarbon migration pathways between lower source rock intervals and higher potential unconventional and conventional reservoir intervals, including the producing Cenozoic stratigraphy of upper Cook Inlet.

The study is part of a UAF Master's thesis (Maley) that focuses on coastal exposures of mostly Upper Jurassic Naknek Formation strata where a broad tide- and wave-cut terrace abuts against coastal bluffs (figs. 13-16), providing threedimensional access to fracture sets in targeted stratigraphic intervals. Fracture data is collected with respect to sedimentary facies and tied to measured sections where possible to develop an understanding of how mechanical stratigraphy controls fracture intensity, length, and continuity. Fracture information is also collected with respect to location relative to faults and folds (for example, fold limbs vs. fold crests, proximity to faults) to understand how fracture systematics change with structural position.

During the 2012 field season, we collected data on a total of 1,750 fractures in Naknek Formation strata on the Iniskin Peninsula and south shore of Kamishak Bay, in lower Cook Inlet, and north shore of Hallo Bay on the upper Alaska Peninsula, as well as from the Upper Cretaceous Kaguyak Formation type section near Swikshak Lagoon on the upper Alaska Peninsula (fig. 1). These data, along with those from additional fracture work scheduled for the summer of 2013 , will be used to determine the mode and relative timing of fracture set development, and provide baseline information about fracture intensity, connectivity, and fill to aid in the development of fracture reservoir models for the Cook Inlet Mesozoic interval.

${ }^{1}$ Alaska Division of Geological \& Geophysical Surveys, 3354 College Rd., Fairbanks, AK 97709-3707

${ }^{2}$ University of Alaska, Fairbanks (UAF), Department of Geology \& Geophysics, P.O. Box 755780, Fairbanks, AK 99775-5780

${ }^{3}$ Alaska Division of Oil \& Gas, 550 W. 7th Ave., Suite 800, Anchorage, AK 99501-3560 


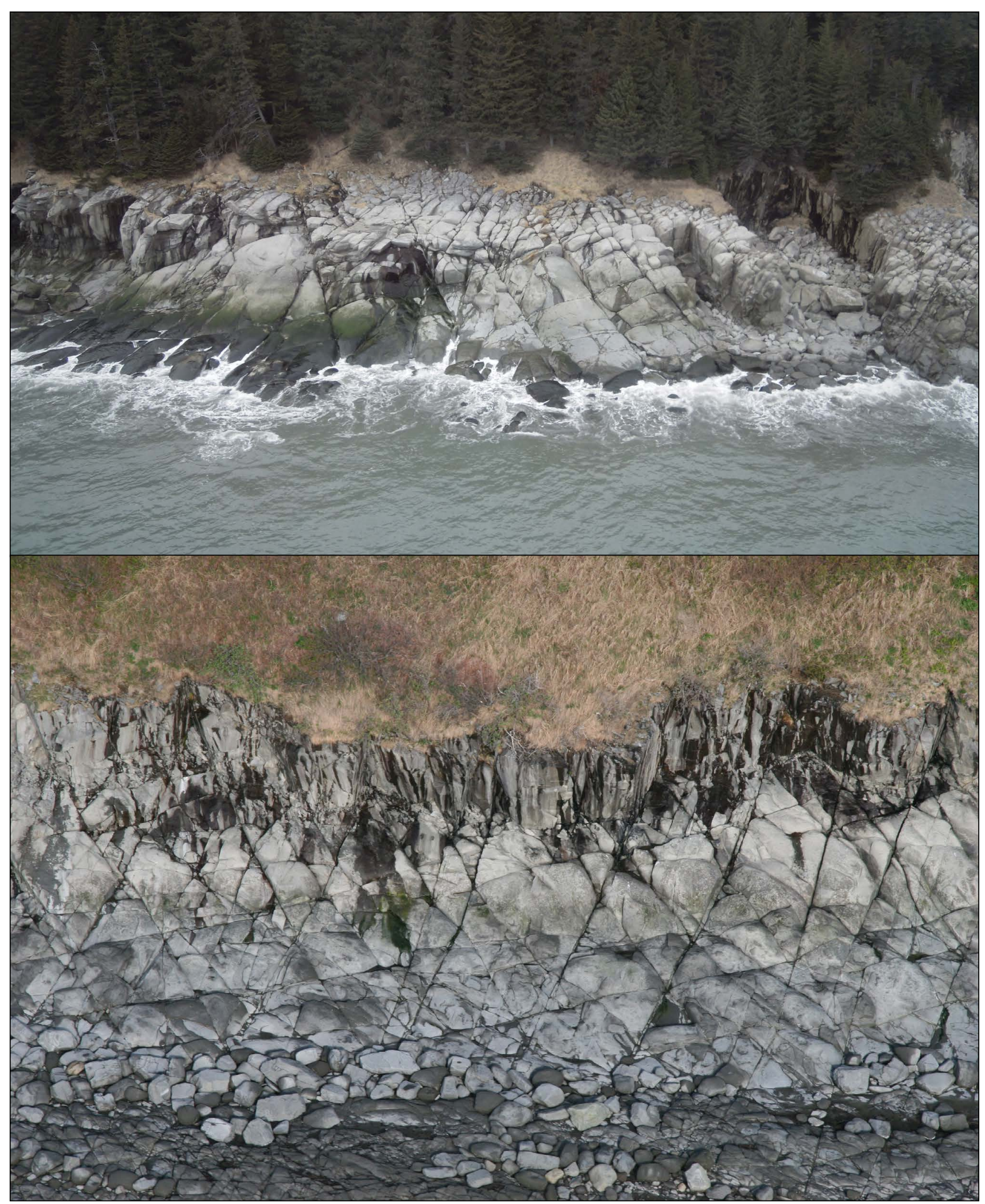

Figure 13. Examples of well developed fracture sets common throughout most of the Mesozoic stratigraphy. Top: Tidal exposure on southeast coast of Iniskin Peninsula (Naknek Formation, Pomeroy Member). Bottom: Oblique plan view of intertidal zone and coastal bluff on east side of Chisik Island (Naknek Formation, Snug Harbor Siltstone Member). Image width approximately $20 \mathrm{~m}$. 


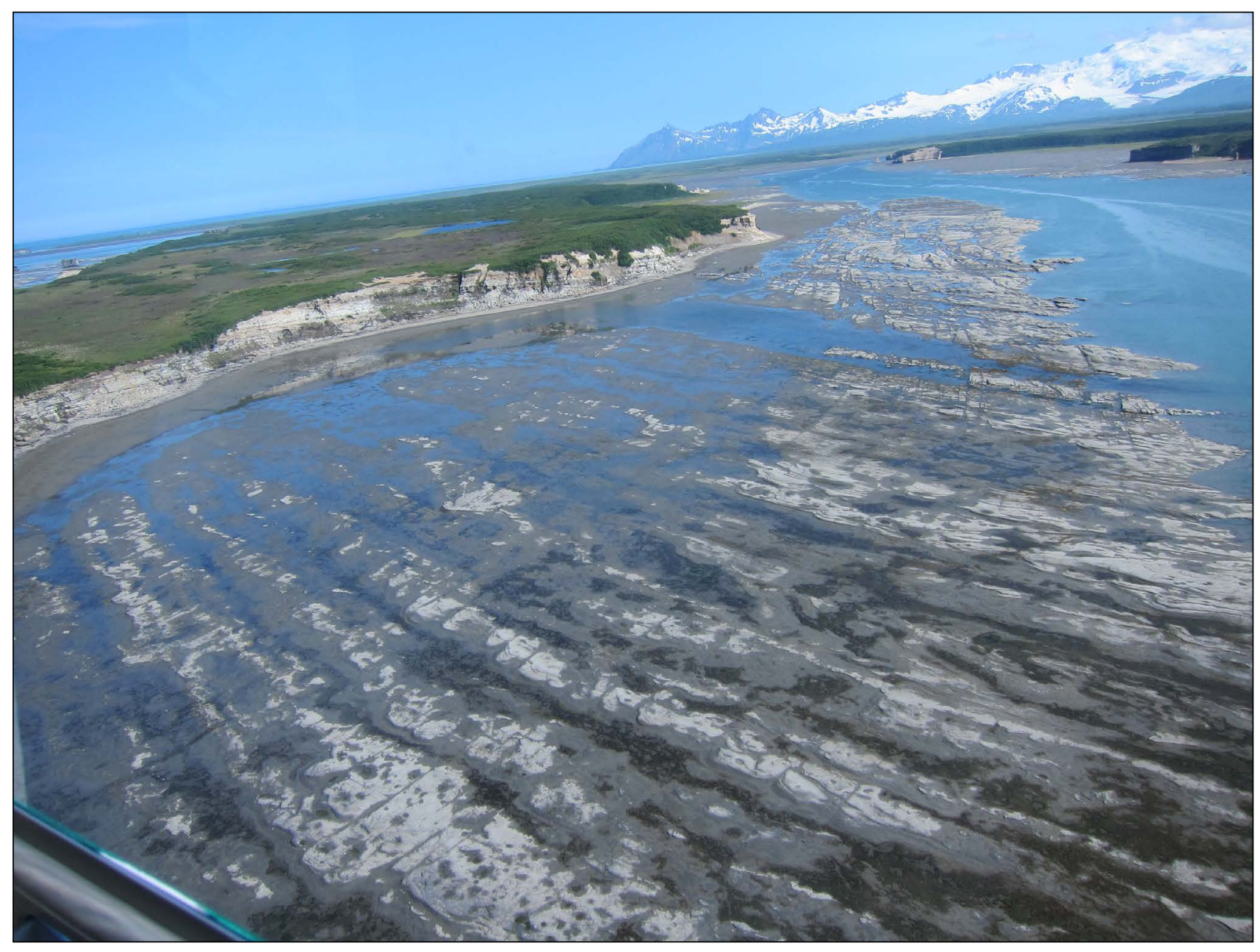

Figure 14. Broad tide- and wave-cut terraces abutting against coastal bluffs of gently dipping strata provide excellent three-dimensional access to fracture systems. Such exposures facilitate easy projection of sedimentary facies packages defined in cross section with correlative terrace exposures, where fracture length and intensity are easiest to quantify. Naknek Formation, Indecision Creek Member, Douglas River Island (informal) off the southern coast of Kamishak Bay, upper Alaska Peninsula. 


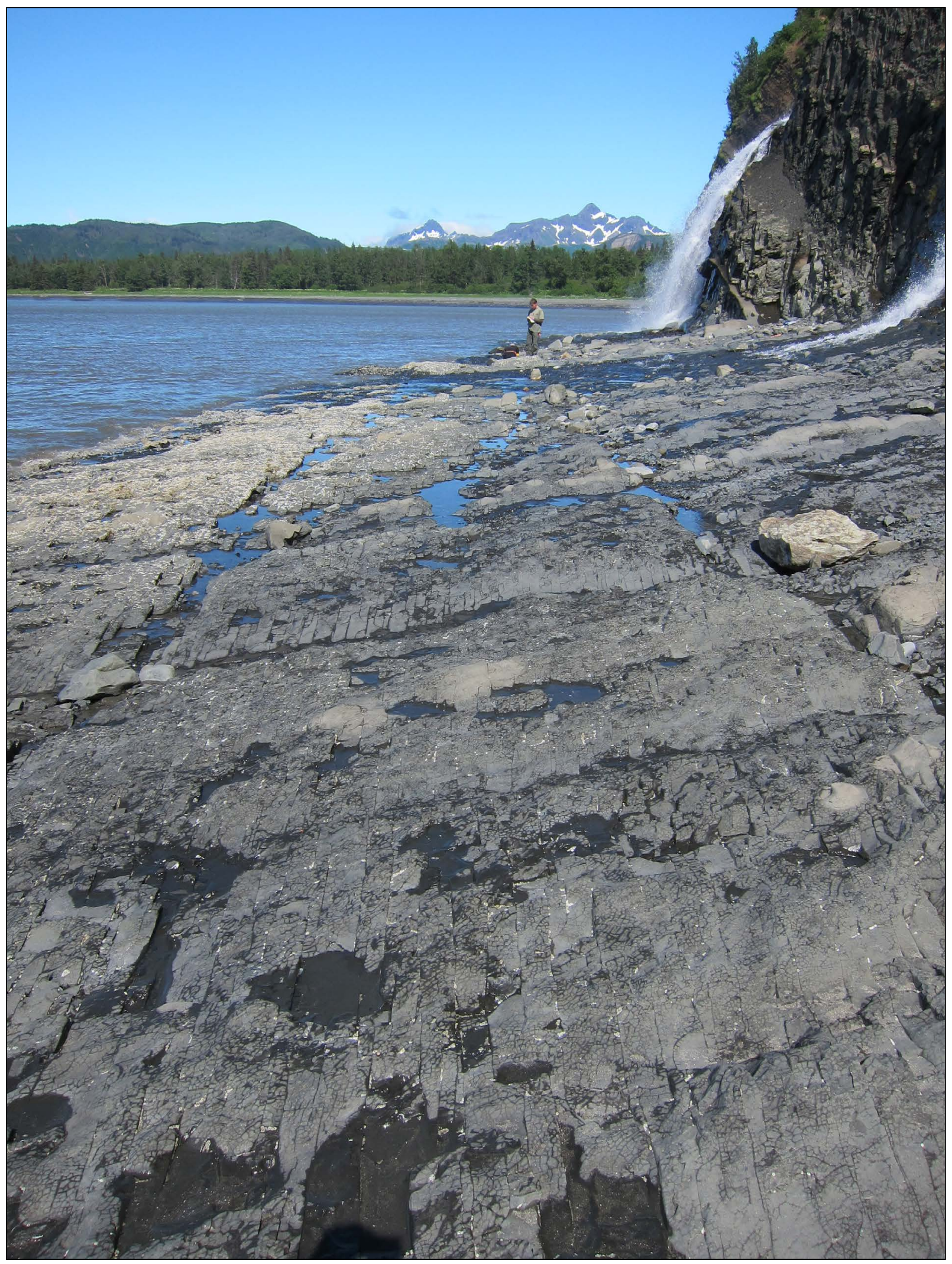

Figure 15. Interface of terrace and bluff exposures showing strata-bound and through-going fracture sets. Chinitna Formation, Paveloff Siltstone Member in Oil Bay on the Iniskin Peninsula (Shaun Peterson for scale). 


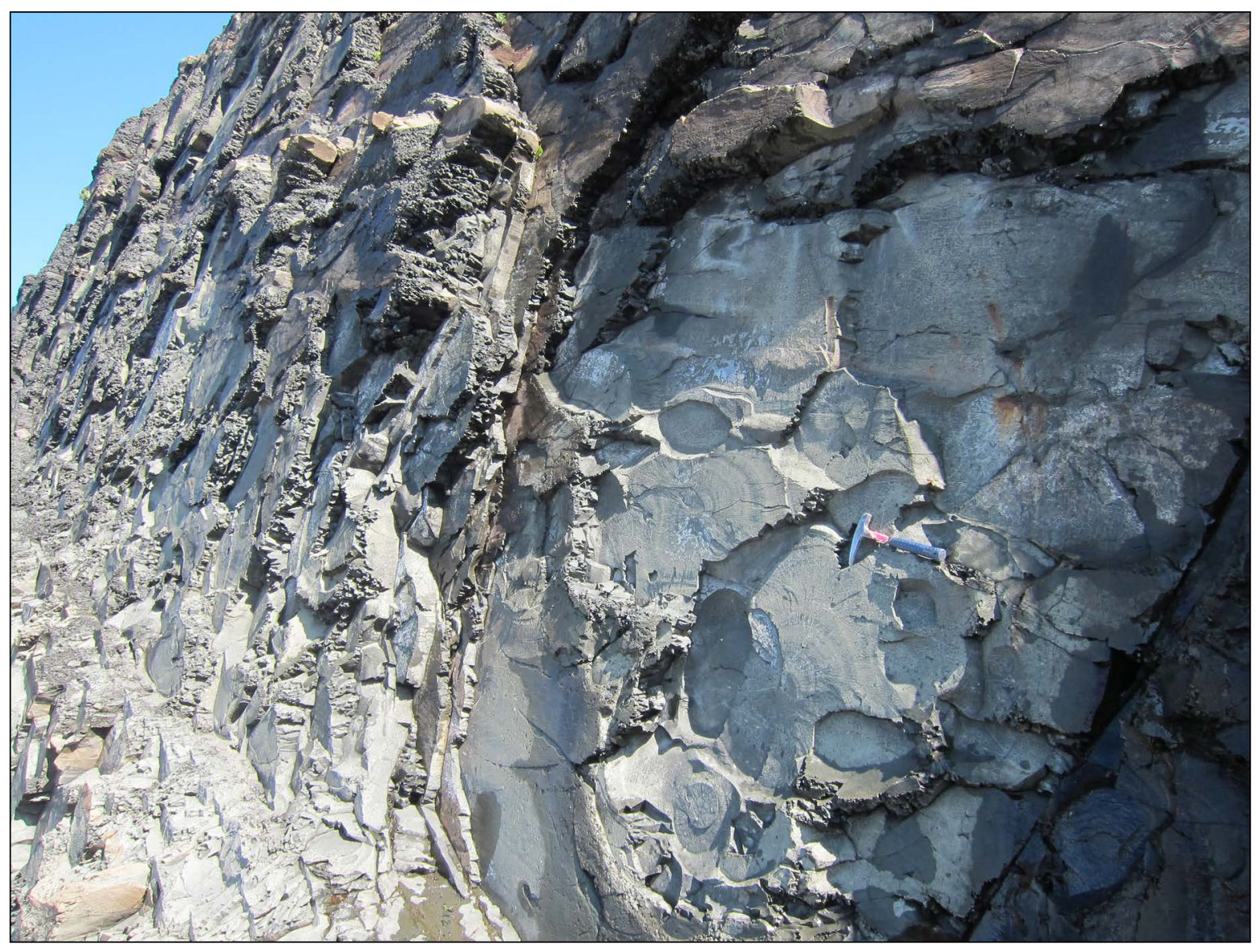

Figure 16. Bluff exposure of Mode I fractures with well expressed plumose structures (hammer for scale). Chinitna Formation, Paveloff Siltstone Member in Oil Bay on the Iniskin Peninsula. 